\title{
Gender Analyses on Knowledge and Awareness of COVID- 19 on Wearing Face Mask Behaviour for Self-Protection among Elderly Malaysians
}

Zumilah Zainalaludin, Hazwan Mat Din, Norehan Saidi, Halimatus Sakdiah Minhat, Raja Nurzatul Efah Raja Adnan \& Siti Aisyah Nor Akahbar

To Link this Article: http://dx.doi.org/10.6007/IJARBSS/v11-i12/11802～DOI:10.6007/IJARBSS/v11-i12/11802

Received: 17 October 2021, Revised: 21 November 2021, Accepted: 04 December 2021

Published Online: 18 December 2021

In-Text Citation: (Zainalaludin et al., 2021)

To Cite this Article: Zainalaludin, Z., Din, H. M., Saidi, N., Minhat, H. S., Adnan, R. N. E. R., \& Akahbar, S. A. N. (2021). Gender Analyses on Knowledge and Awareness of COVID-19 on Wearing Face Mask Behaviour for Self-Protection among Elderly Malaysians. International Journal of Academic Research in Business and Social Sciences, 11(12), 618-636.

Copyright: (c) 2021 The Author(s)

Published by Human Resource Management Academic Research Society (www.hrmars.com) This article is published under the Creative Commons Attribution (CC BY 4.0) license. Anyone may reproduce, distribute, translate and create derivative works of this article (for both commercial and non0-commercial purposes), subject to full attribution to the original publication and authors. The full terms of this license may be seen at: http://creativecommons.org/licences/by/4.0/legalcode

Vol. 11, No. 12, 2021, Pg. $618-636$

Full Terms \& Conditions of access and use can be found at http://hrmars.com/index.php/pages/detail/publication-ethics 


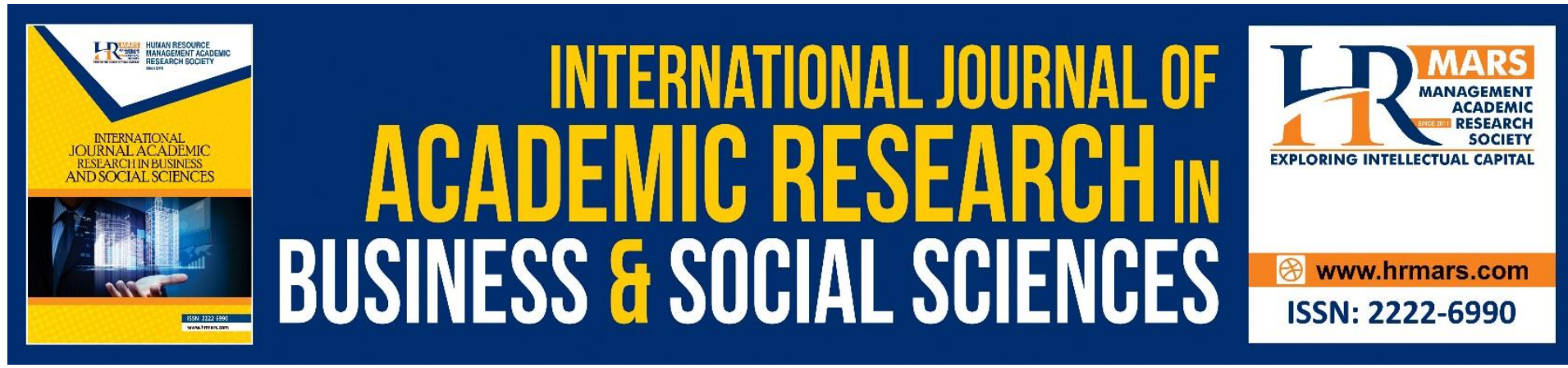

\title{
Gender Analyses on Knowledge and Awareness of COVID-19 on Wearing Face Mask Behaviour for Self-Protection among Elderly Malaysians
}

\author{
1,2Zumilah Zainalaludin, ${ }^{1} \mathrm{Hazwan}$ Mat Din, ${ }^{2}$ Norehan Saidi, \\ ${ }^{3}$ Halimatus Sakdiah Minhat, ${ }^{1}$ Raja Nurzatul Efah Raja Adnan \& \\ ${ }^{1}$ Siti Aisyah Nor Akahbar \\ ${ }^{1}$ Malaysian Research Institute on Ageing, Universiti Putra Malaysia, 43400 Serdang, \\ Selangor, Malaysia, ${ }^{2}$ Faculty of Human Ecology, Universiti Putra Malaysia, 43400 Serdang, \\ Selangor, Malaysia, ${ }^{3}$ Faculty of Medicine and Health Sciences, Universiti Putra Malaysia, \\ 43400 Serdang, Selangor, Malaysia \\ Email: zumilah@upm.edu.my
}

\begin{abstract}
This paper aimed to measure the variable that predicts the likelihood of female respondents to wear face mask. The data were collected $(n=501)$ through online survey using Google Form. The set of questionnaire included the respondents' background, knowledge about COVID-19, the awareness on COVID-19, and behaviour related to COVID-19 protection especially in wearing a face mask, washing hands, and social distance. Respondents in this study comprised the majority of females, Malay ethnic and from urban areas, at average age $=65.55$ years old. Majority (75.25\%) reported that they are unemployed, married (78.24\%), and had tertiary education (74.85\%). Knowledge and awareness on COVID-19 significantly predict respondents to wear face mask. High knowledge predicts 19.194 times the likelihood of respondents to wear face mask, and high awareness predicts that less than $95.6 \%$ of respondents to wear face mask. Nevertheless, no variable predicts male respondents to wear face mask, and only high knowledge in COVID-19 predicts 41.340 times the likelihood of female respondents to wear a face mask. As conclusion, only high knowledge of COVID-19 predicts the behaviour of wearing face mask. Thus, effort should be focused on providing the public with good knowledge of COVID-19 to sustain good behaviour with regard to COVID-19 protection.
\end{abstract}

Keyword: COVID-19, Face Mask, Health Protection, KAP, Older Adult

Introduction

The Coronavirus Disease 2019 (COVID-19) was first reported in December 2019 in Wuhan, China and has since spread extensively triggering a worldwide pandemic in the year 2020. Covid-19 is caused by SARS-CoV2, a novel coronavirus that is one of the seven coronaviruses known to cause disease in humans. Two highly pathogenic in human coronaviruses (HCoVs) are severe acute respiratory syndrome coronavirus (SARS-CoV) and Middle East respiratory 
syndrome coronavirus (MERS-CoV) (Lai et al., 2020). Malaysia and many other countries are facing this pandemic. By $29^{\text {th }}$ December, 2020, there had been 108,605 cases of COVID-19 in Malaysia, and 457 mortality cases. Person-to-person spread occurs through contact with infected secretions, mainly via contact with large respiratory droplets and contact with contaminated surfaces by respiratory droplets. Of the infected patients, $20 \%$ to $30 \%$ required mechanical ventilation and $10 \%$ died, with higher fatality rates in older patients and those with medical comorbidities (Paules et al., 2020).

Currently, some COVID-19 vaccines had been developed by pharmaceutical companies. Due to the high demand, the process of distributing the vaccine may take some times. At the same time, there are cases related to COVID-19 infection among vaccinated individuals, although it is less severe than non-vaccinated individuals (Huang et al., 2021). This scenario shows that self-protection is still necessary, besides getting vaccinated, individual practice of selfprotection from COVID-19 may have extra protection from this deadly virus.

Therefore, everyone needs extra precaution and prevention measures to minimize the spread of COVID-19 virus (Azlan et al., 2020), for instance through frequently Washing hands with water and soap, or sanitizer, Wearing face mask especially in public places and Warning self and others by avoiding handshakes, practising the ethics of coughing and sneezing and getting immediate treatment should symptoms related to COVID-19 (3W) develop, as well as avoiding crowded and confined places as well as close conversation (3C). To practise $3 \mathrm{~W}$ and to avoid the $3 \mathrm{C}$ campaign in Malaysia is to create awareness among Malaysians as well as prevention measures so as to minimize the spread of COVID-19 virus. Nevertheless, these control measures (Practice) will be largely affected by someone's Knowledge and Attitude (awareness) towards COVID-19 (Fan et al., 2018). This paper only focuses on wearing the face mask which is one of the $3 \mathrm{~W}$ measures, from gender perspective.

According to Gender Schema Theory (Bem, 1987), being male is associated with men, and masculinity; female is assumed to be associated with women and femininity. Men have to be involved in generating income in the public sphere for the family, and women have to be involved in the private sphere doing household chores and mostly complying with gendercongruent roles (Voitkane, 2018; Achtenhagen \& Welter, 2011). The society will explain the masculinity and femininity behaviour (Koenig et al., 2011; Gupta et al., 2009). For instance, women have to obey men and the femininity behaviours are regarding following the rules, obedience, fear, and every detail in obtaining the information (Samuelsson, 2020), and the masculinity behaviours are related to power, ego, less tolerance and high-risk taker (Buscher \& Quick, 2005). These gender-related behaviours will work as normative guiding to determine how to take action in the respective schema (Wards, Hansbrough \& Walker, 2005; Bem, 1981). To avoid 3C and to practise 3W for COVID-19 preventions are the new norms for everybody. Gender perspective explains that men and women may react differently to the new norms. Thus, program interventions should address the differences of men and women to comply with the $3 \mathrm{~W}$ and to avoid the $3 \mathrm{C}$.

\section{Objectives}

This paper only focuses on wearing face mask as one of the $3 \mathrm{~W}$ measures, which is very important and easy to practise. Generally, this paper aimed to discuss the knowledge and awareness domains in predicting older male and female behaviours in wearing face mask for 
COVID-19 prevention. In detail, this paper aimed to achieve four research objectives as follows:-

1. To profile the backgrounds of older respondents

2. To measure the variable that predicts the likelihood of older respondents to wear face mask

3. To measure the variable that predicts the likelihood of male older respondents to wear face mask

4. To measure the variable that predicts the likelihood of female older respondents to wear face mask.

\section{Literature Review Health Protection}

Generally, health protection focuses on preventing the spread of communicable diseases which aims at reducing the likelihood that people will encounter environmental hazards or behave in unsafe or unhealthy ways. Health promotion strategies are meant to influence better health or hygienic practices, and thereby reduce the risk of spreading outbreaks (Galvan, 2017). World Health Organization (WHO) recommends infection prevention and control which is a practical and evidence-based approach to avoid infections in which resulted in a more than 30\% reduction in healthcare-associated infections (Hearn et al., 2017).

In Malaysia, the Ministry of Health adopted the 3W measures by increasing the awareness of the public on the importance to adhere and practise the $3 \mathrm{Ws}$ (Ministry of Health, Malaysia, 2020; Prevent Epidemics, 2020). Wearing a face mask and hygiene practices through washing hands may reduce pathogen transmission in health care by $50 \%$ (Pradhan et al., 2020). According to the Centers for Disease Control (CDC), spacing of $6 \mathrm{ft}$. away (social distancing) may decrease the spread of COVID-19 (Centers for Disease Control, 2019), and may flatten the pandemic curve (Sen-Crowe et al., 2020).

\section{Knowledge, Awareness and Practice (KAP) Theory on Prevention Behaviour}

Knowledge, awareness and practice are domains in KAP Theory which was firstly explained on health-related behaviours. The generation of attitudes and adoption of behaviour is influenced by related knowledge and the awareness of the behavior (Fan et al., 2018). For example, the attitude on wearing the face mask for COVID-19 protection by an individual is influenced by his/her knowledge of the danger of COVID-19, and the awareness on the importance of self-protection from COVID-19. Nevertheless, the behaviour of wearing a face mask can be imposed through legislation for emergency protection (Madi \& Hussain, 2008). In the medium term, the public should clearly understand why they have to adhere to the law to wear a face mask in public areas. In long term, the public should be self-empowered to wear a face mask for an epidemic and to a pandemic.

In discussing human behaviour, gender perspective may play an important role, especially for sex-disaggregated intervention program planning. This paper uses KAP Theory and gender analyses to explain someone's behaviours on the health regulation to wear face mask in public areas. The KAP was divided into three successive processes which were the acquisition of the right knowledge, generation of attitudes and adoption of behaviour (practice) (Fan et al., 2018). The knowledge domain in this paper is the knowledge on COVID-19 - the virus, the 
pandemic and the emergency behaviours. The generation of attitude domain refers to the awareness of someone on the danger of COVID-19 and the importance to practise selfprotection as advised.

Many studies have shown a significant association between knowledge and the awareness on prevention behaviours as well as the management of the disease (Matsumoto-Takahashi et al., 2015; Rana et al., 2015; Khalil \& Abdalrahim, 2014). The paucities of KAP are linked to poor health and maladaptive disease preventive behaviour (Ricardo et al., 2018; Toovey et al., 2004). Hence, a person with high KAP may play a decisive role in the battle against COVID-19 (Pal et al., 2020), especially among the elderly because they are in the high-risk group (Bwire, 2020; WHO, 2020; Chhetri et al., 2020).

People need extra precaution and prevention measures to minimize the spread of COVID-19 virus (Azlan et al., 2020), because COVID-19 vaccine and any definite therapy against COVID19 are still under study. In other words, self-protection behaviours are essential currently. Hence, the KAP of someone may play a decisive role in the battle against COVID-19 (Pal et al., 2020), especially among older adults. Older adult is one of the high-risk groups in COVID-19, which may be due to poor immune system and at the same time they might have already suffered from various diseases which make them prone to COVID-19 (WHO, 2020; Chhetri et al., 2020). COVID-19 pandemic involves emergency actions and the new norms that lead to anxiety, stress and insomnia along with fear among older adults (Takieddine $\&$ Tabbas, 2020) especially those in nursing homes (Chee, 2020).

The feminization of ageing shows that women live longer than men (United Nation, 2019), and many older and poor women than older and poor men in any community (Adisa, 2019; Eboiyehi, 2013). Poverty makes them have less access to health services, thus they are vulnerable to various diseases in which these diseases such as hypertension, diabetes and heart diseases make them more prone to COVID-19 (WHO, 2020; Chhetri et al., 2020). For example in China, 81 percent of COVID-19 patients are older adults (Guo et al., 2020). Thus, various social studies that explain COVID-19 and older adult population are crucial.

In an emergency, health protection can be achieved through the development and implementation of legislation (Madi \& Hussain, 2008). In long term, this may help in national health planning process; besides a key implementation mechanism, to convert major health policy objectives into action through establishing standards (Clarke, 2016). Nevertheless, for the people to follow the standards and guidelines for good practices, they must have sufficient knowledge, and good attitudes towards the legislation (Tulchinsky \& Varavikov, 2014). People aren't always committed to the rules and regulations, or 'accidents' may happen without conscious intent (Burgess, 1999). Moreover, in the new normal environment in which people may not have sufficient knowledge and a good awareness of COVID-19 to comply with the rules and regulations related to its prevention. In addition to the "mundane" nature of not complying with the regulations after the Movement Control Order (MCO) is too long, and this may create more harmful behaviour (Feldma et al., 2019), especially among older adults.

WHO has then developed an overarching legal framework through International Health Regulations (2005) (IHR) that defines countries' rights and obligations in handling public 
health events and emergencies. The Ministry of Health Malaysia has set up several guidelines to prevent the virus from spreading widely - the Prevention and Control of Infectious Diseases (Measures within the Infected Local Areas) Regulations 2020 ('Phase 1 Regulations'), and Prevention and Control of Infectious Diseases (Measures within Infected Local Areas) (No. 2) Regulations 2020 ('Phase 2 Regulations') on 18 March 2020 and 31 March 2020 respectively (SKRINE, 2020).

\section{Gender-Related Behaviour on Regulation Compliance}

The practice of wearing face mask in public areas is considered the easiest practice among the $3 \mathrm{~W}$ because this is an individual decision whether to wear a face mask or not. The Gender Schema Theory (Bem, 1987) assumes males are associated with men and masculinity, and females are assumed to be associated with women and femininity. Generally, men are expected to be involved in income-generating activities and the public sphere, and women are designated to the private sphere doing household chores and mostly complying with gender-congruent roles (Voitkane, 2018; Achtenhagen \& Welter, 2011). Masculine to men and feminine to women are gender stereotypes that are according to the culture to define the level of masculinity and femininity (Koenig et al., 2011; Gupta et al., 2009). The assumption in Gender Schema Theory works as normative guiding to determine how to act in the respective schema (Wards et al., 2005; Bem, 1981).

Besides health and science studies, social studies are essential to understand human behaviours on COVID-19 protection, because these behaviours are essential to control the spread of COVID-19 diseases. COVID-19 has a significant impact on gender, for instance, men are more likely to engage in health-related risk (Walter \& McGregor, 2020) and are more prone to COVID-19 (Bwire, 2020). For example, not wearing a face mask in public areas is a high-risk behaviour in a pandemic environment, and is associated with masculinity and men. Another example is washing hands, which is associated with work at home, women and the private sphere (Voitkane, 2018; Achtenhagen \& Welter, 2011), as well as following the rules and instructions. In Patriarchal Theory, men have more power against women (Sultana, 2010), and women must obey men in a family (Adisa et al., 2019). Women are associated with weakness and obedience behaviours and men are associated with strong and protective behaviour (Mir-Hosseini, 2019). These may explain that women are more obedient than men in practising the $3 \mathrm{~W}$.

Gender stereotypes promote different standards for women and men in a similar activity (Wood \& Eagly, 2012; Eagly \& Karau, 2002); for instance in practising the 3W during COVID19 pandemic (Berkhout \& Richardson, 2020). According to Lewis (2020), COVID-19 has been called "a disaster for feminism" because the care obligations within pandemic negatively impact women. In Mukhtar (2020), women and girls will identify themselves in the pandemic while having an awareness of their own needs, and working with the resistance which requires full phenomenological awareness. Besides that, women give positive thought and creating healthy boundaries with others in a pandemic (Mukhtar, 2020). Men are also more vulnerable than women to COVID-19 (Bwire, 2020). Bem as in Witt and Wood (2010) explained the internal motivation among males and females may help to regulate his or her behaviour. This may help males and females prompt their behaviour during the COVID-19 pandemic such as wearing the face mask, keeping the social distancing and washing their hands. Wood et al (1997) also showed the evidence that people regulate their behaviour in 
daily life influenced by their psychology. Bwire (2020) also stated that women have a more responsible attitude towards the regulation during COVD-19 pandemic than men on 3W.

\section{Methods}

A cross-sectional survey was conducted among older Malaysian population. According to United Nations, 60+ years old is used to refer to older population (United Nation, 2008; Kowal \& Dowd, 2001). According to the Department of Statistics Malaysia (2019), there was an estimated 3.35 million older adult population in the year 2019 in Malaysia. A sample size calculator was used to estimate the required sample size, to achieve the study objectives and sufficient statistical power. The calculator arrived at 385 respondents, with a margin of error of $\pm 5 \%$, a confidence interval of $95 \%$, a $50 \%$ response distribution, and 3.35 million older adults. As the sample size increases, the external validity and generalizability of the study also increase (Cavana et al., 2001). This study aimed to maximize the reach and gather data from as many respondents as possible.

\section{Null Hypotheses}

$\mathrm{H}_{\mathrm{O}-1}$ : no variable predicts the likelihood of older respondents to wear a face mask.

$\mathrm{H}_{\mathrm{O}-2}$ : no variable predicts the likelihood of older male respondents to wear a face mask.

$\mathrm{H}_{\mathrm{O}-3}$ : no variable predicts the likelihood of older female respondents to wear a face mask.

\section{Questionnaire}

One set of questionnaire consisted of the background of older respondents, the knowledge and awareness on COVID-19 and the practices on self-protection was specially developed (Appendix 1). The ethical approval for this study was obtained from Universiti Putra Malaysia Ethics Committee for Involving Human Subject (JKEUPM-2020-231). This paper only focuses on the Knowledge, Awareness and Practices of COVID-19 self-protection related to wearing the face mask behaviour.

There were 14 statements measuring the knowledge on COVID-19. Each statement was measured through two scales in this paper - Know $=1=$ high, and don't know \& False $=0=$ Low. Four statements were used to measure the awareness on COVID-19. Each statement was measured through two scales - agree $=1=$ high awareness, and don't know \& disagree $=0=$ low awareness. This paper only used one dichotomous dependent variable (DV) which is wearing a face mask when leaving home $=\mathrm{YES}=1$, and not wearing a face mask $=\mathrm{NO}=0$.

\section{Data Collection}

The data collection was conducted from 18th June to 21st June 2020 through an online survey via self-reported questionnaire using Google Form. The main reason for using an online survey was because of the recovery movement control order (RMCO) that was announced by Malaysian Government one week before the data collection started. The link of the questionnaire was distributed among the MyAgeing ${ }^{\mathrm{TM}}$ researchers' network. The link was also posted on the official website and Facebook page of MyAgeing ${ }^{\mathrm{TM}}$.

\section{Binary Logistic Regression Model}

In this paper, one Binary Logistic Regression (BLR) Model was used to test each null hypothesis. The three BLR models used in this paper are as follows:- 
BLR Model $1-\operatorname{Ln} Y_{a l l}=a+b_{\text {knowledge }}+b_{\text {awareness }}$

Note:

i) For all older respondents

ii) Dependent variable (DV) as follows:-

YES, I am wearing a face mask $=1$

NO, I am not wearing a face mask $=0$

iii) Model significant $(p<0.05)$

iv) Knowledge and awareness variables have significant $(p<0.05)$ relationship with the DV and no multicollinerarity

BLR Model $1-\operatorname{Ln} Y_{\text {male }}=a+b_{\text {knowledge }}+b_{\text {awareness }}$

Note:

i) For all male older respondents

ii) Dependent variable (DV) as follows:-

YES, I am wearing a face mask $=1$

NO, I am not wearing a face mask $=0$

iii) Model significant $(p<0.05)$

iv) Knowledge and awareness variables have significant $(p<0.05)$ relationship with the DV and no multicollinerarity

BLR Model $3-\operatorname{Ln} Y_{\text {female }}=a+b_{\text {knowledge }}+b_{\text {awareness }}$

Note:

i) For all female older respondents

ii) Dependent variable (DV) as follows:-

YES, I am wearing a face mask $=1$

NO, I am not wearing a face mask $=0$

iii) Model significant $(p<0.05)$

iv) Knowledge and awareness variables have significant $(p<0.05)$ relationship with the DV and no multicollinerarity

\section{Findings and Discussion}

Profiles of the Respondents

Five hundred one older respondents aged 60 and above answered the online survey. There were about one third (33.53\%) older males, and almost two-third (66.47\%) older female respondents. Their mean age was equal to 64.55 years old (SD=4.771 years old) in the year 2020. The mean age of male older respondents was equal to 65.43 years old ( $S D=5.27$ years old), and equal to 64.10 years old ( $S D=4.4$ years old) for female older respondents in the year 2020. In this study, old age $=60$ years old (United Nation, 2008). Thus, only respondents of age 60 and above can participate in the study. On average, the males in this study are slightly older than the female respondents (Table 1). From older respondents in this research, the majority $(78.25 \%)$ was in the married category, and 21.76 percent in single category of the marital status. Older age population is always associated with feminization because female on average lives longer than male (United Nations, 2019). Thus, there are many older females than older males in any community. The feminization of the elderly community may cause the two-third responses from female respondents as compared to only one-third responses from male respondents, besides the females' femininity behaviours regarding the detail in 
doing things (Samuelsson, 2020) which may also lead to many females than males in responding to the survey.

The number of respondents participated in this study comprised largely Malays (64.88\%), and a small percentage of Chinese (24.55\%), 5.79 percent of Indians and 4.79 percent of other races. Almost three quarters (74.85\%) of older respondents had a tertiary academic background, 22.55 percent had secondary school education and only 2.6 percent had primary and below level of academic background. They are educated and may be involved in professional careers in their adult age (Table 1) because the majority of them reported their working status as currently unemployed (75.25\%) which may also mean retired. Urban areas offer a large variety of jobs compared to rural areas (Litsaidotoulos et al., 2020), especially among those with good academic background, in which this paper reported 88.82 percent of respondents from urban areas. There are three reasons supported by the data that the respondents previously had professional careers - because of tertiary academic qualification, from urban areas, and currently unemployed job status. There is a high probability for them to get involved in a good career before retiring because of the academic background - tertiary education, as according to Tentama and Abdillah (2019), there is a relationship between academic background and career development or profession, in which someone with a university degree may have a high potential to have a good career. The respondents are majority from urban areas with varieties of jobs (Litsaidotoulos et al., 2020). Obviously, rural populations are usually associated with low academic background (Zainalaludin, 2012).

Table 1 shows that 16.57 percent of older respondents reported being self-employed, which is associated with entrepreneurial activities. Some older adults choose to be entrepreneurial after retirement because there are better business opportunities in urban areas (Smeaton, 2003), and some older adults may be entrepreneurs because of their entrepreneurial experiences in adulthood (Henley, 2007).

The majority of older respondents in this study was from female group, Malay ethnicity and from urban areas, at average age $=65.55$ years old, with male ( 65.43 years old), slightly older than female ( 64.10 years old). About three quarters (75.25\%) reported being unemployed, married $(78.24 \%)$, and with a tertiary background of education $(74.85 \%)$. With these statistics, they may be unemployed because they have already retired. 
Table 1: Profiles of the Respondents ( $n=501)$

\begin{tabular}{|c|c|c|c|c|c|c|c|}
\hline \multirow{2}{*}{ Variable } & \multirow{2}{*}{ Category } & \multicolumn{2}{|c|}{ Male } & \multicolumn{2}{|c|}{ Female } & \multicolumn{2}{|c|}{ Total } \\
\hline & & $n$ & $\%$ & $n$ & $\%$ & $n$ & $\%$ \\
\hline \multirow[t]{4}{*}{ Race } & Malay & 130 & 77.38 & 195 & 58.56 & 325 & 64.87 \\
\hline & Chinese & 20 & 11.90 & 103 & 30.93 & 123 & 24.55 \\
\hline & Indian & 9 & 5.36 & 20 & 6.01 & 29 & 5.79 \\
\hline & Others & 9 & 5.36 & 15 & 4.50 & 24 & 4.79 \\
\hline TOTAL & & 168 & 33.53 & 333 & 66.47 & 501 & 100 \\
\hline Academic & Primary \& below & 4 & 2.38 & 9 & 2.70 & 13 & 2.60 \\
\hline \multirow[t]{2}{*}{ Background } & Secondary & 39 & 23.21 & 74 & 22.22 & 113 & 22.55 \\
\hline & Tertiary & 125 & 74.41 & 250 & 75.08 & 375 & 74.85 \\
\hline TOTAL & & 168 & 100 & 333 & 100 & 501 & 100 \\
\hline \multirow[t]{2}{*}{ Marital Status } & Single & 11 & 6.55 & 98 & 29.43 & 109 & 21.76 \\
\hline & Married & 157 & 93.45 & 235 & 70.57 & 392 & 78.24 \\
\hline TOTAL & & 168 & 100 & 333 & 100 & 501 & 100 \\
\hline Working & Unemployed & 118 & 70.24 & 259 & 77.78 & 377 & 75.25 \\
\hline \multirow[t]{2}{*}{ Status } & Paid work & 10 & 5.95 & 31 & 9.31 & 41 & 8.18 \\
\hline & Self-employed & 40 & 23.81 & 43 & 12.91 & 83 & 16.57 \\
\hline TOTAL & & 168 & 100 & 333 & 100 & 501 & 100 \\
\hline \multirow{2}{*}{$\begin{array}{l}\text { Current Place } \\
\text { of Residence }\end{array}$} & Rural & 22 & 13.10 & 34 & 10.21 & 56 & 11.18 \\
\hline & Urban & 146 & 86.90 & 299 & 89.79 & 445 & 88.82 \\
\hline TOTAL & & 168 & 100 & 333 & 100 & 501 & 100 \\
\hline Age & Mean & \multicolumn{2}{|c|}{65.43} & \multicolumn{2}{|c|}{64.10} & \multicolumn{2}{|c|}{64.55} \\
\hline (Years Old) & SD & \multicolumn{2}{|c|}{5.27} & \multicolumn{2}{|c|}{4.44} & \multicolumn{2}{|c|}{4.771} \\
\hline
\end{tabular}

Variable that Predicts the Likelihood of Respondents to Wear Face Mask

One Binary Logistic Regression (BLR) Model (BLR Model 1) was used in this paper to achieve the RO-2: to measure the variable that predicts the likelihood of older respondents to wear face mask. DV is a dichotomous variable which was YES, I am wearing a face mask =1, and, NO, I am not wearing a face mask $=0$. The two IVs were knowledge (high=1, low=0), and awareness ( $h i g h=1$, low $=0$ ) variables of COVID-19. The $\mathrm{H}_{\mathrm{O}-1}$ (no variable predicts the likelihood of older respondents in wearing a face mask) was tested to achieve the RO-2. Omnibus Model Coefficient showed that BLR Model 1 was significant $(p<0.05)$ to be used in predicting the wearing of face mask behaviour among older respondents through their knowledge and awareness of COVID-19. The Wald Chi-Square Table (Table 2) shows the knowledge and awareness level of COVID-19 significantly $(p<0.05)$ predict the likelihood of older respondents in wearing face mask. High knowledge of COVID-19 predicts 19.194 times of the likelihood of older respondents to wear face mask for COVID-19 protection. Nevertheless, high awareness of COVID-19 predicts 95.6 percent less of the likelihood of older respondents in wearing face mask (Table 2). 
Table 2: Wald Chi-Square Table of Knowledge and Awareness Predictor Variable on Older Respondent to Wear Face Mask (YES wear face mask=1)

\begin{tabular}{lrrrrrr}
\hline Predictor Variable & B & S.E. & Wald & df & Sig. & Exp.(B) \\
\hline Knowledge (high) & 2.955 & 1.473 & 4.023 & 1 & .045 & 19.194 \\
Awareness (high) & -3.119 & 1.476 & 4.464 & 1 & .035 & .044 \\
Constant & 2.769 & 1.380 & 4.023 & 1 & .045 & 15.939 \\
\hline
\end{tabular}

These findings show that older respondents with high knowledge of COVID-19 may show a high likelihood of wearing a face mask. These are aligned with previous findings on the relationship between knowledge and behaviour in which someone's behaviour on something is influenced by his/her knowledge related to the behaviour (Fan et al., 2018). Hence, high KAP level of someone may play a decisive role in the battle against COVID-19 (Pal et al., 2020). This paper concludes that among older adults, high knowledge of COVID-19 influences their behaviour in wearing face mask for COVID-19 protection. Nevertheless, high awareness of COVID-19 showed otherwise. Thus, only knowledge and not the awareness of COVID-19 may be useful to assist older adults in practising self-protection by wearing a face mask. As according to WHO (2020) and Chhetri et al (2020), older adults are vulnerable and in high risk group to COVID-19. They have to be equipped with sufficient knowledge of COVID-19. Thus, social studies have to focus on various socio-economic and socio-demographic variables to develop efficient intervention programs and legislation to reduce the risk of spreading the outbreak.

The significant relationships between knowledge and behaviour on something were obtained in many studies. For instance, knowledge and attitude on wearing a face mask in Uganda (Sikakulya et al., 2021); knowledge on environmental-care behaviours among river population (Alias, 2019); and knowledge and behaviour on self-protection behaviour of COVID-19 among general Malaysians (Azlan et al., 2020). All these studies may support the importance of the government to deliver sufficient knowledge on COVID-19 to promote self-protection behaviours - wear a face mask, wash hands and keep the distance from others.

\section{Variable that Predicts the Likelihood of Male Respondents to Wear Face Mask}

In this sub-topic, the $\mathrm{H}_{\mathrm{O}-2}$ (no variable predicts the likelihood of older male respondents to wear a face mask) was tested to achieve the RO-3 (to measure the variable that predicts the likelihood of older male respondents to wear face mask). One Binary Logistic Regression Model (Model 2) was used to achieve the RO-3. A similar dichotomous DV as in BLR Model 1 was used in BLR Model 2. However, Omnibus Model Coefficient showed that Model 2 was not significant $(p>0.05)$ to be used in predicting the wearing of face mask behaviour among older male respondents. The Wald Chi-Square Table (Table 3) demonstrates that there is no variable which significantly predicts the likelihood of older male respondents in wearing face mask. Thus, $\mathrm{H}_{\mathrm{o}-2}$ was failed to reject. The knowledge and awareness on COVID-19 do not significantly $(p>0.05)$ predict male older respondents in wearing the face mask (Table 3$)$. 
Table 3: Wald Chi-Square Table of Knowledge and Awareness Predictor Variable on Male Respondent to Wear Face Mask (yes wear face mask=1)

\begin{tabular}{lrrrrrr}
\hline Predictor Variable & B & S.E. & Wald & df & Sig. & Exp.(B) \\
\hline Knowledge (high) & -16.121 & 20096.485 & .000 & 1 & .999 & .000 \\
Awareness (high) & 16.121 & 28420.721 & .000 & 1 & 1.000 & 10034005.235 \\
Constant & 21.203 & 20096.485 & .000 & 1 & .999 & 1615474825.794 \\
\hline
\end{tabular}

The findings from BLR Model 2 showed almost two-third (66.47\%) of older women than about one third $(33.53 \%)$ of older men were reported in this paper. Since there is a higher COVID19 risk among men than among women (Bwire, 2020; WHO, 2020, Chhetri et al., 2020), further studies are essential to confirm male behaviour towards health protection on COVID19. Emergency interventions are crucial for older men if the findings in future studies persistently show knowledge and awareness of men on COVID-19 do not significantly predict their behaviour, especially in complying with $3 \mathrm{~W}$ and avoiding $3 \mathrm{C}$.

There is a high death risk due to COVID-19 among male than female patients (Peckham et al., 2020). Thus, serious and more detailed studies have to be conducted among males to know the indicators that could explain the high risk among male than female individuals on the death risk due to COVID-19. This research discovered that knowledge and awareness do not significantly predict male behaviour of wearing face mask for self-protection.

\section{Variable that Predicts the Likelihood of Female Respondents to Wear Face Mask}

One Binary Logistic Regression Model (BLR Model 3) was used to achieve the RO-4 (to measure the variables that predict the likelihood of female older respondents to wear face mask). One null hypothesis - $\mathrm{H}_{\mathrm{O}-3}$ (no variable predicts the likelihood of older female respondents to wear a face mask) was tested on BLR Model 3. A similar dichotomous DV as in Model 1 and 2 was used in Model 3. Omnibus Model Coefficient of Model 3 was significant $(p<0.05)$ to be used in predicting the wearing of face mask behaviour among older female respondents through knowledge and awareness of COVID-19. The Wald Chi-Square Table (Table 4 ) shows that only high knowledge significantly predicts $(p<0.05)$ the likelihood of older female respondents in wearing face mask. High knowledge of COVID-19 predicts 41.34 times the likelihood of older female respondents to wear face mask. HO-3 is rejected. This paper concludes that high knowledge of COVID-19 predicts older female respondents in wearing face mask.

Table 4: Wald Chi-Square Table of Knowledge and Awareness Predictor Variable on Female Older Respondent to Wear Face Mask (YES wear face mask=1)

\begin{tabular}{lrrrrrr}
\hline Predictor Variable & B & S.E. & Wald & df & Sig. & Exp.(B) \\
\hline Knowledge (high) & 3.722 & 1.869 & 3.966 & 1 & .046 & 41.340 \\
Awareness (high) & -3.411 & 1.862 & 3.355 & 1 & .067 & .033 \\
Constant & 2.359 & 1.740 & 1.838 & 1 & .175 & 10.585 \\
\hline
\end{tabular}

The findings on RO-4 showed only knowledge on COVID-19 (high) predicts older female behaviour in wearing face mask. This is in line with Fan, et al.'s (2018) study. The findings demonstrate a high impact among older females in wearing face mask if she has high knowledge of COVID-19. This finding is again aligned with previous findings on the 
relationship between knowledge and behaviour (Fan et al., 2018). Improving public knowledge on COVID-19 may play a decisive role in the battle against COVID-19 (Pal et al., 2020). This paper concludes that among older female adults, high knowledge of COVID-19 influences his/her behaviour in wearing face mask for COVID-19 protection. The likelihood of female older respondents in wearing a face mask in Table 4 is 41.340 times, more than double the likelihood of the respondents in general (Table 2) which is 19.194 times likelihood. According to Wood et al., (1997), the regulation of people's behaviour in their daily life is influenced by their psychology. In the case of COVID-19, women have a more responsible attitude towards COVID1-19 pandemic than men on 3W (Bwire, 2020), and give positive thought, and create healthy boundaries with others in the pandemic (Mukhtar, 2020). Extra effort should be given to improve the programs to inform the public on COVID-19 especially among older adults and utilize females in the family.

\section{Conclusion and Recommendation}

This paper concludes that in general, a high knowledge of COVID-19 positively and significantly predicts the likelihood of older Malaysians in wearing facemask for COVID-19 protection. Nevertheless, only high knowledge on COVID-19 predicts high practice of wearing face mask, while high awareness significantly predicts otherwise - predicts less likelihood of older Malaysians in wearing face mask. Thus, focus should be given to equip older respondents with the knowledge on self-protection against COVID-19.

Through gender analyses, only among female older adults, and only high knowledge variable significantly predicted the likelihood of older adults and female older adults to wear face mask for self-protection. No variable significantly predicts older male respondents to wear face mask. There is a higher COVID-19 risk among male than female older adults, nevertheless this paper reported only about one-third of male older adult respondents which may cause an insignificant result among them. This paper concludes self-protection behaviors on COVID-19 are gender-related. Thus, program intervention programs should be gender-sensitive and targeting right groups by sex disaggregation.

This paper recommends gender-sensitive program and further studies:-

1) government to continue and increase the knowledge-transfer programs on COVID-19 to various target groups, because adults and the elderly may be influenced by the grandchildren for right self-protection behaviours.

2) knowledge can also be transferred through various channels such as local drama because the elderly people usually prefer to watch local dramas.

3) wearing face mask campaigns as well as other self-protection behaviours should be continued especially on TV and social media.

4) the campaign to spread knowledge on COVID-19 should be elderly-friendly by taking into consideration the dynamic of the elderlies' backgrounds such as using popular older actor/artist to attract the attention of the elderly.

5) future studies have to be conducted from social point of view to observe and identify more predictor variables which significantly explain the behaviour regarding self- protection from COVID-19 by sex disaggregation. These predictor variables are important to develop program interventions for specific group with high risk of COVID-19.

6) future studies also have to compare and highlight self-protection from COVID-19 behaviour by various socio-economic backgrounds. For instance, strata, poverty, 
vulnerability, academic background, economic sector, and profession of the respondents. The findings with regard to various backgrounds may help in intervention programs and planning identifying variables that need extra care and budget allocations.

7) future studies should focus on more data among male older adults and male elderly to observe the predictor variables that explain their health self-protection behaviours.

8) future studies may focus on other methods of data collection, improved questionnaire, or through qualitative data collection method.

\section{Limitation}

The findings in this paper may be limited to online data collection method, the questionnaire and the elderly as the background of the respondents. The findings in this paper are limited to the respondents which confirm the problem statements exist in the elderly population in Malaysia. Thus, further study can be designed to address this issue in more detailed measures. This paper is also limited to wearing a facemask for COVID-19 self-protection behaviour only.

\section{Acknowledgement}

An acknowledgment to Medical Gerontology Laboratory, Malaysian Research Institute on Ageing (MyAgeing ${ }^{\mathrm{TM}}$ ), Universiti Putra Malaysia for the data. The study was led by Mr Hazwan Mat Din.

\section{References}

Achtenhagen, L., \& Welter, F. (2011). 'Surfing on the ironing board'-the representation of women's entrepreneurship in German newspapers. Entrepreneurship \& Regional Development, 23(9-10), 763-786.

Adisa, O. (2019). Why are some older persons economically vulnerable and others not? The role of socio-demographic factors and economic resources in the Nigerian context. Ageing International, 44(2), 202-222.

Adisa, T., Abdulraheem, I., \& Isiaka, S. B. (2019). Patriarchal hegemony: Investigating the impact of patriarchy on women's work-life balance. Gender in Management: An International Journal, 34(1), 19-33. DOI 10.1108/GM-07-2018-0095

Alias, N. A. (2019). Correlation between Knowledge, Attitude and Behaviour towards River Pollution. International Journal of Modern Trends in Social Sciences, 2(9), 31-38. DOI: 10.35631/IJMTSS.29004

Azlan, A. A., Hamzah, M. R., Sern, T. J., Ayub, S. H., \& Mohamad, E. (2020). Public knowledge, attitudes, and practices towards COVID-19: A cross-sectional study in Malaysia. PLoS ONE, 15(5): e0233668. https://doi.org/10.1371/journal.pone.0233668

Bem, S. (1981). Bem sex-role inventory: Professional manual. Palo Alto, CA: Consulting Psychologists Press, Inc.

Bem, S. L. (1987). Gender schema theory and the romantic tradition. In P. Shaver \& C. Hendrick (Eds.), Sex and gender (pp. 251-271). Sage Publications, Inc.

Berkhout, S. G., \& Richardson, L. (2020). Identity, politics, and the pandemic: Why is COVID19 a disaster for feminism (s)?. History and Philosophy of the Life Sciences, 42(4), 1-6. https://doi.org/10.1007/s40656-020-00346-7

Burgess, C. (1999). Breaking the rules: Why do people behave in the way they do? Report for the Accident Prevention Task Group. Retrieved from https://people.exeter.ac.uk/cnwburge/pages/Rule-breaking.html 
Buscher, D., \& Quick, D. (2005). Masculinities: male roles and male involvement in the promotion of gender equality: a resource packet. Women's Commission for Refugee Women and Children.

Bwire, G. M. (2020). Coronavirus: why men are more vulnerable to Covid-19 than women? SN Comprehensive Clinical Medicine, 2(7), 874-876 https://doi.org/10.1007/s42399-02000341-w

Cavana, R., Delahaye, B., \& Sekeran, U. (2001). Applied Business Research: Qualitative and Quantitative Methods. John Wiley \& Sons.

Centers for Disease Control. (2019). Transmission of Coronavirus Disease (COVID-19). and Prevention. https://www.cdc.gov/coronavirus/2019-ncov/prepare/transmission.html; March 4, 2020. Accessed date: 22 March 2020.

Chee, S. Y. (2020). COVID-19 Pandemic: The Lived Experiences of Older Adults in Aged Care Homes. Millennial Asia, 0976399620958326.

Chhetri, J. K., Chan, P., Arai, H., Park, S. C., Gunaratne, P. S., Setiati, S., \& Assantachai, P. (2020). Prevention of COVID-19 in older adults: a brief guidance from the International Association for Gerontology and Geriatrics (IAGG) Asia/Oceania region. The Journal of Nutrition, Health \& Aging, 24(5), 471-472.

Clarke, D. (2016). Law, Regulation and Strategizing for Health.Strategizing National Health in the $21^{\text {st }}$ Century: A Handbook World Health Organisation. Retrieved from https://www.who.int/publications/i/item/strategizing-national-health-in-the-21stcentury-ahandbook

Department of Statistics Malaysia. (2019). Population projections (Revised), Malaysia, 20102040. Available at:

https://www.dosm.gov.my/v1/index.php?r=column/cthemeByCat\&cat=118\&bul_id=Y 3kwU2tSNVFDOWp1YmtZYnhUeVBEdz09\&menu_id=LOpheU43NWJwRWVSZkIWdzQ4 TIhUUT09

Eagly, A. H., \& Karau, S. J. (2002). Role congruity theory of prejudice toward female leaders. Psychological Review, 109(3), 573.

Eboiyehi, F. A. (2013). Elderly widows and poverty: Empirical evidence from rural Nigeria. Journal of International Social Research, 6(26).

Fan, Y., Zhang, S., Li, Y., Li, Y., Zhang, T., Liu, W., \& Jiang, H. (2018). Development and psychometric testing of the Knowledge, Attitudes, and Practices (KAP) questionnaire among student Tuberculosis (TB) Patients (STBP-KAPQ) in China. BMC Infectious Diseases, 18(1), 213.

Feldman, Y, Rorie, M., \& Van Rooij, B. (2019) Rule-breaking without Crime: Insights from Behavioural Ethics for the Study of Everyday Deviancy. The Criminologist, 44(2), 8-11.

Galvan, M. (2017). Health Promotion vs Health Protection. Retrieved from https://www.concentra.com/resource-center/articles/health-promotion-vshealthprotection/

Guo, T., Shen, Q., Guo, W., He, W., Li, J., Zhang, Y., ... \& Peng, H. (2020). Clinical characteristics of elderly patients with COVID-19 in Hunan Province, China: a multicenter, retrospective study. Gerontology, 66(5), 467-475.

Gupta, V. K., Turban, D. B., Wasti, S. A., \& Sikdar, A. (2009). The role of gender stereotypes in perceptions of entrepreneurs and intentions to become an entrepreneur. Entrepreneurship Theory and Practice, 33(2), 397-417. 
Hearn P, Miliya T, Seng S, Ngoun, C., Day, N.P.D., Lubell, Y., Turner, C., \& Turner, P. (2017). Prospective surveillance of healthcare healthcare-associated infections in a Cambodian pediatric hospital. Antimicrob Resistance \& Infection Control, 6(1), 1-9.

Henley, A. (2007). Entrepreneurial aspiration and transition into self-employment: evidence from British longitudinal data. Entrepreneurship \& Regional Development, 19(3), 253280.

Husni Madi, D \& Hussain, S. J. (2008). Editorial: Health protection and promotion. Eastern Mediterranean Health Journal,14(Supplement): S15-S22.

Kementerian Kesihatan Malaysia. (2020). Kenyataan Akhbar KPK 18 Mei 2020 Situasi Semasa Jangkitan Penyakit Coronavirus 2019 (COVID-19) di Malaysia. Retrieved from https://kpkesihatan.com/2020/05/18/kenyataan-akhbar-kpk-18-mei-2020-situasisemasajangkitan-penyakit-coronavirus-2019-covid-19-di-malaysia

Khalil, A., \& Abdalrahim, M. (2014). Knowledge, attitudes, and practices towards prevention and early detection of chronic kidney disease. International Nursing Review, 61(2), 237245.

Koenig, A. M., Eagly, A. H., Mitchell, A. A., \& Ristikari, T. (2011). Are leader stereotypes masculine? A meta-analysis of three research paradigms. Psychological Bulletin, 137(4), 616.

Kowal, P., \& Dowd, J. E. (2001). Definition of an older person. Proposed working definition of an older person in Africa for the MDS Project. World Health Organization, Geneva, doi, 10(2.1), 5188-9286.

Lai, C. C., Shih, T. P., Ko, W. C., Tang, H. J., \& Hsueh, P. R. (2020). Severe acute respiratory syndrome coronavirus 2 (SARS-CoV-2) and coronavirus disease-2019 (COVID-19): The epidemic and the challenges. International Journal of Antimicrobial Agents, 55(3), 105924.

Lewis, H. (2020). The coronavirus is a disaster for feminism. The Atlantic. 19 March 2020. https://www.theatlantic.com/international/archive/2020/03/feminism-womensrightscoronavirus-covid19/608302/ Accessed 18 December 2020.

Litsardopoulos, N., Saridakis, G., \& Hand, C. (2020). The effects of rural and urban areas on time allocated in self-employment: differences between men and women. Sustainability, 12(17), 7049.

Matsumoto-Takahashi, E. L. A., Tongol-Rivera, P., Villacorte, E. A., Angluben, R. U., Jimba, M. \& Kano, S. (2015). Patient knowledge on malaria symptoms is a key to promoting universal access of patients to effective malaria treatment in Palawan, the Philippines. PLoS One, 10(6), e0127858.

Mir-Hosseini, Z. (2019). The challenges of islamic feminism. Gender a Výzkum, 20(2), 108-122. Mukhtar, S. (2020). Feminism and gendered impact of COVID-19: Perspective of a counselling psychologist. Gender, Work \& Organization, 27(5), 827-832. DOI: 10.1111/gwao.12482

Pal, R., Yadav, U., Grover, S., Saboo, B., Verma, A., \& Bhadada, S. K. (2020). Knowledge, attitudes and practices towards COVID-19 among young adults with Type 1 Diabetes Mellitus amid the nationwide lockdown in India: A cross-sectional survey. Diabetes Research and Clinical Practice, 166, 108344.

Paules, C. I., Marston, H. D., \& Fauci, A. S. (2020). Coronavirus infections-more than just the common cold. Jama, 323(8), 707-708.

Peckham, H., de Gruijter, N. M., Raine, C., Radziszewska, A., Ciurtin, C., Wedderburn, L. R., Rosser, E. C., Webb, K., \& Deakin, C. T. (2020). Male sex identified by global COVID-19 
meta-analysis as a risk factor for death and ITU admission. Nature Communications, 11(1), 1-10.

Pradhan, D., Biswasroy, P., Naik, P. K., Ghosh, G., \& Rath, G. (2020). A review of current interventions for COVID-19 prevention. Archives of Medical Research, 51(5), 363-374.

Prevent Epidemics. (2020). 3 W's to reduce the risk of COVID-19, retrieved from https://preventepidemics.org/covid19/science/insights/3-ws-to-reduce-the-risk-ofcovid-19/14

Rana, M., Sayem, A., Karim, R., Islam, N., Islam, R., Zaman, T. K., \& Hossain, G. (2015). Assessment of knowledge regarding tuberculosis among non-medical university students in Bangladesh: a cross-sectional study. BMC Public Health, 15(1), 716.

Ricardo, T., Bergero, L. C., Bulgarella, E. P., \& Previtali, M. A. (2018). Knowledge, attitudes and practices (KAP) regarding leptospirosis among residents of riverside settlements of Santa Fe, Argentina. PLoS Neglected Tropical Diseases, 12(5), e0006470.

Samuelsson, M. (2020). Shakespeare's Representation of Women: A Feminist Reading of Shakespeare's Hamlet.

Sen-Crowe, B., McKenney, M., \& Elkbuli, A. (2020). Social distancing during the COVID-19 pandemic: Staying home save lives. The American Journal of Emergency Medicine, 38(7), 1519-1520.

Sikakulya, F. K., Ssebuufu, R., Mambo, S. B., Pius, T., Kabanyoro, A., Kamahoro, E., Mulumba, Y., Muhongya, J. K., \& Kyamanywa, P. (2021). Use of face masks to limit the spread of the COVID-19 among western Ugandans: Knowledge, attitude and practices. Plos One, 16(3), e0248706.

SKRINE. (2020). Malaysia: Covid-19: Regulations To Implement Movement Control Order In Malaysia. Retrieved from https://www.mondaq.com/healthcare/926732/covid-19regulations-toimplement-movement-control-order-in-malaysia.

Smeaton, D. (2003). Self-employed workers: calling the shots or hesitant independents? A consideration of the trends. Work, Employment and Society, 17(2), 379-391.

Sultana, A. (2010). Patriarchy and Women s Subordination: A Theoretical Analysis. Arts Faculty Journal, 1-18.

Takieddine, H., \& Tabbah, S. A. (2020). Coronavirus pandemic: coping with the psychological outcomes, mental changes, and the "new normal" during and after COVID-19. Open Journal Depression Anxiety, 2, 7-19.

Tentama, F., \& Abdillah, M. H. (2019). Student Employability Examined from Academic Achievement and Self-Concept. International Journal of Evaluation and Research in Education, 8(2), 243-248.

Toovey, S., Jamieson, A., \& Holloway, M. (2004). Travelers' knowledge, attitudes and practices on the prevention of infectious diseases: results from a study at Johannesburg International Airport. Journal of Travel Medicine, 11(1), 16-22.

Tulchinsky, T. H., \& Varavikov, E. A. (2014). Expanding the Concept of Public Health. The New Public Health (Third Edition). Retrieved from https://www.sciencedirect.com/topics/socialsciences/health-awareness

United Nation. (2008). Guide to the national implementation of the Madrid international plan of action on ageing, department of economic and social affairs United Nations (2019).

United Nations (2019). World Population Ageing 2019: Highlights (ST/ESA/SER.A/430).

Voitkane, A. (2018). Under the surface: Revealing how gender imbalance is created in governmental venture capitalists' work processes (Doctoral dissertation, Luleå University of Technology). 
Walter, L. A., \& McGregor, A. J. (2020). Sex-and Gender-specific Observations and Implications for COVID-19. Western Journal of Emergency Medicine, 21(3), 507. https://doi.org/10.5811/westjem.2020.4.47536

Ward, L. M., Hansbrough, E., \& Walker, E. (2005). Contributions of music video exposure to black adolescents' gender and sexual schemas. Journal of Adolescent Research, 20(2), 143-166.

Witt, M. G., \& Wood, W. (2010). Self-regulation of gendered behavior in everyday life. Sex Roles, 62(9-10), 635-646. DOI 10.1007/s11199-010-9761-y

Wood, W., \& Eagly, A. H. (2012). Biosocial construction of sex differences and similarities in behaviour. In Advances in Experimental Social Psychology, 46, 55-123.

Wood, W., Christensen, P. N., Hebl, M. R., \& Rothgerber, H. (1997). Conformity to sex-typed norms, affect, and the self-concept. Journal of Personality and Social Psychology, 73(3), 523. https://doi.org/10.1037/0022-3514.73.3.523

World Health Organization. (2020). Guidance on COVID-19 for the care of older people and people living in long-term care facilities, other non-acute care facilities and home care. Retrieve from file:///C:/Users/user/Downloads/COVID-19-emergency-guidanceageing-eng\%20.pdf

Zainalaludin Z. (2012). Scaling up rural micro enterprises: Profiles of owners in Peninsular Malaysia. Pertanika Journal of Social Sciences \& Humanities, 20(4), 1049-1064. 


\section{Appendix 1}

\section{Questions on the KAP}

\begin{tabular}{|c|c|}
\hline KAP & Question \\
\hline Knowledge & 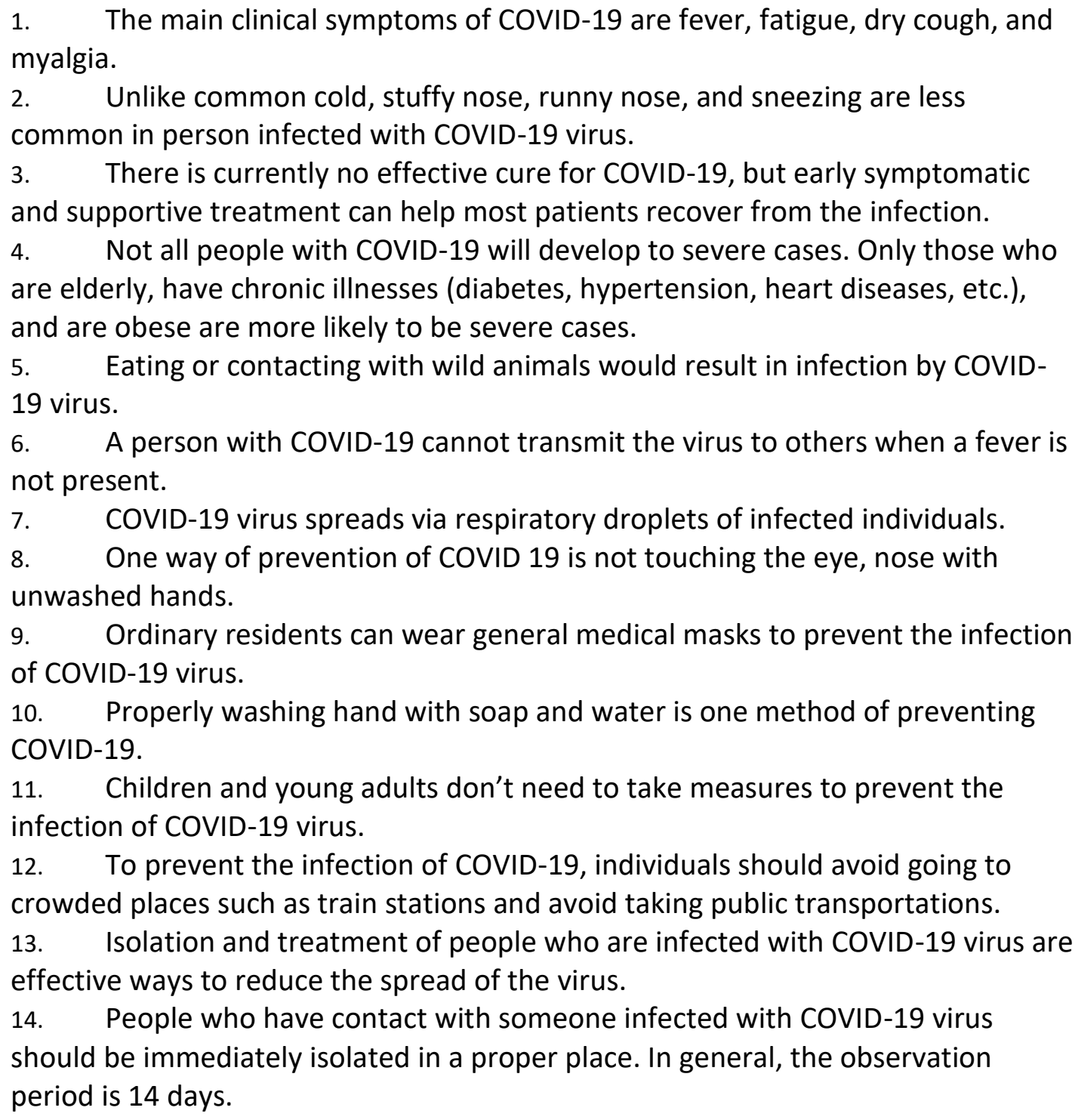 \\
\hline Awareness & $\begin{array}{l}\text { 1. It is important to keep my distance from others, to avoid spreading COVID- } \\
19 \\
2 . \\
\text { of COVID-19. } \\
\text { 3. Do you agree that COVID-19 will finally be successfully controlled in } \\
\text { Malaysia? } \\
4 . \quad \text { Do you have confidence that Malaysia can win the battle against the } \\
\text { COVID-19 virus? }\end{array}$ \\
\hline Practice & In recent days, have you worn a mask when leaving home? \\
\hline
\end{tabular}

